\title{
ANALISIS PENGARUH PROMOSI, LOKASI, HARGA, DAN KUALITAS PELAYANAN TERHADAP KEPUTUSAN PEMBELIAN PADA ROTI BAKAR 88 TANGERANG
}

\author{
Anna Yulianingsih \\ Alumni Program Manajemen S1 \\ Sekolah Tinggi Ilmu Ekonomi Bisnis Indonesia \\ Sutarti \\ Dosen STIE Bisnis Indonesia, Jakarta
}

\begin{abstract}
The purpose of this study is to find out how much influence Promotion, Location, Price and Quality Service to the Purchase Decision on Baked Bakar 88 Tangerang. This type of research is survey research with quantitative approach, where research is done by taking some samples from the population and using questionnaires as data gathering tools. The population of this study is 2500 consumers. In this study using a sample of 100 respondents. The research method used primary data. Sampling technique using Accidental Sampling and processed by using SPSS 22.00. From the results of the study showed that all independent variables (Promotion, Location, Price, and Service Quality) simultaneously or together effect on the Purchase Decision on Baking Bakar 88 Tangerang. Judging from the value of correlation coefficient $(R)$ of 0.789 there is a strong relationship between Promotion variables, Location, Price and Quality of Service to Purchase Decision. Then from the calculation of Coefficient of Determination (R2), it can be concluded that the independent variables in this study has an Adjusted $R$ Square value of 0.606 or $60.6 \%$, it shows that the percentage of contribution variable Promotion, Location, Price, and Service Quality Giving influence of 60.6\%, to Purchasing Decision on Baking Baked 88 Tangerang while the rest equal to 39.4\% influenced other factor not included in this research.
\end{abstract}

Keywords: Promotion, Location, Price, Service Quality, and Purchase Decision.

Abstrak: Tujuan dari penelitian ini adalah untuk mengetahui seberapa besar pengaruh Promosi, Lokasi, Harga dan Kualitas Pelayanan terhadap Keputusan Pembelian pada Roti Bakar 88 Tangerang. Jenis penelitian ini adalah penelitian survey dengan pendekatan kuantitatif, dimana penelitian yang dilakukan dengan mengambil beberapa sampel dari populasi dan menggunakan kuesioner sebagai alat pengumpul data. Populasi dari penelitian ini adalah 2500 konsumen. Dalam penelitian ini menggunakan sampel sebanyak 100 responden. Metode penelitian menggunakan data primer. Teknik pengambilan sampelnya menggunakan Accidental Sampling dan diolah dengan menggunakan SPSS 22.00. Dari hasil penelitian menunjukkan bahwa seluruh variabel bebas (Promosi, Lokasi, Harga, dan Kualitas Pelayanan) berpengaruh secara simultan atau bersama-sama terhadap Keputusan Pembelian pada Roti Bakar 88 Tangerang. Dilihat dari nilai koefisien korelasi (R) sebesar 0,789 terdapat hubungan yang kuat antara variabel Promosi, 
Lokasi, Harga dan Kualitas Pelayanan terhadap Keputusan Pembelian. Kemudian dari hasil perhitungan Koefisien Determinasi $\left(\mathrm{R}^{2}\right)$, dapat disimpulkan bahwa variabel-variabel bebas dalam penelitian ini memiliki nilai Adjusted $R$ Square sebesar 0,606 atau 60,6\%, hal ini menunjukkan bahwa persentase sumbangan variabel Promosi, Lokasi, Harga, dan Kualitas Pelayanan dapat memberikan pengaruh sebesar 60,6\%, terhadap Keputusan Pembelian pada Roti Bakar 88 Tangerang sedangkan sisanya sebesar 39,4\% dipengaruhi faktor lain yang tidak dimasukkan dalam penelitian ini.

Kata Kunci: Promosi, Lokasi, Harga, Kualitas Pelayanan, dan Keputusan Pembelian

\section{PENDAHULUAN}

Dalam menghadapi lingkungan persaingan yang semakin kuat dan ketat, setiap pelaku bisnis dituntut harus mampu meramu serangkaian strategi pemasaran yang efektif dan selalu mengembangkan strategi pemasaran tersebut secara terus-menerus serta berkelanjutan. Hal ini dilakukan sebagai upaya untuk meraih keunggulan kompetitif terhadap para pesaing. Untuk dapat bertahan dan berkembang, pengelola bisnis dituntut untuk mampu menciptakan keunggulan bersaing atas promosi, lokasi, harga, dan kualitas pelayanan dalam upaya memuaskan pembeli dan menghadapi persaingan dalam bisnis ini. Salah satu bisnis kuliner yang berkembang saat ini adalah Roti Bakar 88 yang selalu memberikan inovasi pada setiap menunya dan bahkan memberikan promosi sehingga Roti Bakar 88 dapat bersaing ketat dengan kafe yang sudah ada sebelumnya. Dalam strategi pemasaran Roti Bakar 88 menggunakan beberapa strategi diantaranya seperti promosi, lokasi, harga, dan kualitas pelayanan. Masing-masing variabel akan saling berkaitan. Pengembangan penjualan dapat disesuaikan dengan selera konsumen, dengan harapan para konsumen merasa puas akan jasa yang telah diberikan atau diperjual belikan. Dalam upaya mendatangkan konsumen dan mempertahankan konsumen, yaitu menumbuhkan minat beli dan akhirnya melakukan keputusan pembelian.

Banyak faktor yang mempengaruhi hal itu. Baik dari faktor internal dalam diri konsumen ataupun pengaruh eksternal yaitu rangsangan luar yang dilakukan oleh pelaku usaha, dimana dalam hal ini perusahaan atau pelaku usaha harus mampu mengidentifikasi perilaku konsumen dalam hubungannya melakukan suatu keputusan pembelian. Salah satu faktor penting dalam Roti Bakar 88 Tangerang yaitu pada promosi. Dharmamesta dan Irawan (2010:349), "Promosi adalah arus informasi atau persuasi satu arah yang dibuat untuk mengarahkan seseorang atau organisasi kepada tindakan yang menciptakan pertukaran dalam pemasaran”. Promosi yang dilakukan harus dapat menarik perhatian masyarakat luas sehingga dengan adanya promosi diharapkan konsumen akan mengetahui, terpengaruh, dan memutuskan untuk membeli. Faktor lokasi berpengaruh terhadap keputusan yang diambil konsumen untuk membeli suatu produk. Lokasi yang mudah dijangkau oleh konsumen dan dekat dengan pusat keramaian merupakan lokasi yang tepat untuk suatu usaha, termasuk usaha Roti Bakar 88. Sebelum seseorang atau sekelompok orang memutuskan untuk makan atau minum di sebuah kafe, mereka juga akan mempertimbangkan lokasi tempat kafe tersebut. Selain ditinjau dari lokasi, faktor harga juga merupakan hal penting yang menjadi pertimbangan konsumen. Definisi harga menurut Kotler dan Keller (2010:85) adalah sejumlah uang yang ditukarkan untuk sebuah produk atau jasa. Lebih jauh lagi, harga adalah jumlah dari seluruh nilai yang konsumen tukarkan untuk jumlah manfaat dengan memiliki atau menggunakan suatu barang dan jasa. Penentuan harga produk maupun jasa yang dilakukan perusahaan sangat berpengaruh pada keputusan konsumen.

Setelah mempertimbangkan promosi, lokasi, dan harga, konsumen juga mempertimbangkan kualitas pelayanan. Konsumen mengharapkan adanya kesesuaian antara 
promosi, lokasi, dan harga dengan kualitas pelayanan yang mereka terima. Pelayanan adalah setiap tindakan atau kegiatan yang dapat ditawarkan oleh suatu pihak kepada pihak lain, yang pada dasarnya tidak berwujud dan tidak mengakibatkan kepemilikan apapun. Menurut Tjiptono (2009:59), "Kualitas pelayanan merupakan tingkat keunggulan yang diharapkan dan pengendalian atas tingkat keunggulan tersebut untuk memenuhi keinginan pelanggan”.Pengambilan keputusan oleh konsumen dalam membeli suatu barang maupun jasa tentunya berbeda, bergantung pada jenis keputusan pembelian yang diinginkannya. Menurut Kotler dan Amstrong (2009:179) proses keputusan pembelian terbagi menjadi lima tahapan yaitu pengenalan kebutuhan, pencarian informasi, evaluasi alternatif, keputusan pembelian, dan perilaku pasca pembelian. Berdasarkan pemikiran dan uraian di atas, penulis tertarik untuk melakukan penelitian dengan judul "Analisis Pengaruh Promosi, Lokasi, Harga, Dan Kualitas Pelayanan Terhadap Keputusan Pembelian Pada Roti Bakar 88 Tangerang”.

\section{LANDASAN TEORI}

\subsection{Promosi}

Menurut Dharmamesta dan Irawan (2010:349), "Promosi adalah arus informasi atau persuasi satu arah yang dibuat untuk mengarahkan seseorang atau organisasi kepada tindakan yang menciptakan pertukaran dalam pemasaran”. Menurut Tan (2011:27), "Promosi berkaitan dengan berbagai kegiatan yang dilakukan perusahaan untuk mencoba menyusun komunikasi antara kebaikan produknya dan membujuk para pelanggan serta konsumen sasaran untuk membeli produknya”. Sedangkan menurut Subagyo (2010:129), "Promosi adalah semua kegiatan yang dimaksudkan untuk menyampaikan atau mengkomunikasikan suatu produk kepada pasar sasaran, untuk memberi informasi tentang keistimewaan, kegunaan dan yang paling penting adalah tentang keberadaannya, untuk mengubah sikap ataupun untuk mendorong orang untuk bertindak dalam membeli suatu produk”.

\subsection{Lokasi}

Menurut Kotler (2008:52), "Lokasi adalah salah satu kunci menuju sukses adalah lokasi, lokasi dimulai dengan memilih komunitas. Keputusan ini sangat bergantung pada potensi pertumbuhan ekonomis dan stabilitas, persaingan, iklim politik, dan sebagainya”. Menurut Utami (2012:89), "Lokasi merupakan struktur fisik dari sebuah usaha yang merupakan komponen utama yang terlihat dalam membentuk kesan sebuah usaha yang dilakukan perusahaan dalam melakukan penempatan usahanya dan kegiatan dalam menyediakan saluran pelayanan yang dibutuhkan oleh konsumen.

\subsection{Harga}

Menurut Kotler dan Keller (2012:67), "Harga adalah salah satu elemen bauran pemasaran yang menghasilkan pendapatan, elemen lain menghasilkan biaya”. Mungkin harga adalah elemen termudah dalam program pemasaran untuk disesuaikan, fitur produk, saluran, dan bahkan komunikasi membutuhkan lebih banyak waktu. Harga juga mengkomunikasikan positioning nilai yang dimaksudkan dari produk atau merek perusahaan ke pasar. Produk yang dirancang dan dipasarkan dengan baik dapat dijual dengan harga tinggi dan menghasilkan laba yang besar. Menurut Sumarni (2011:285), "Harga adalah jumlah uang (ditambah beberapa produk kalau mungkin) yang dibutuhkan untuk mendapatkan sejumlah kombinasi dari produk dan pelayanannya”. Sedangkan menurut Alma (2016:169), "Harga adalah nilai suatu barang yang dinyatakan dengan uang”. Menurut Fure (2013:275), “Harga adalah sejumlah uang yang 
ditukarkan untuk produk atau jasa. Menurut Sutojo (2009:58), "Harga adalah bagian penting yang tidak terpisahkan dari marketing mix, karena juga tidak dapat dipisahkan dari ketiga komponen marketing mix yang lain yaitu produk, distribusi dan promosi penjualan”.

\subsection{Kualitas Pelayanan}

Pengertian kualitas layanan berpusat pada upaya pemenuhan kebutuhan dan keinginan pelanggan serta ketepatan penyampaian untuk mengimbangi harapan pelanggan. Menurut Kotler dan Keller (2009:180), "Kualitas layanan adalah keseluruhan fitur dan sifat produksi atau pelayanan yang berpengaruh pada kemampuannya untuk memuaskan kebutuhan yang dinyatakan atau yang tersirat. Menurut Tjiptono dan Chandra (2011:180), "Mendefinisikan kualitas pelayanan sebagai ukuran seberapa baik tingkatan layanan yang diberikan mampu sesuai dengan ekspektasi pelanggan”.

\subsection{Keputusan Pembelian}

Menurut Kotler (2012:184), "Keputusan Pembelian yaitu beberapa tahapan yang dilakukan oleh konsumen sebelum melakukan keputusan pembelian suatu produk”. Dari pendapat tersebut dapat disimpulkan bahwa untuk melakukan suatu keputusan orang akan melalui suatu proses tertentu, demikian pula pada hal keputusan memilih produk atau merek mereka akan melaksanakan proses terlebih dahulu mungkin karena mereka tidak mau menanggung resiko apabila pembelian produk tersebut, sehingga mereka akan penuh dengan pertimbangan-pertimbangan.

\subsection{Kerangka Pikir}

Gambar 2.1.

Kerangka Pikir

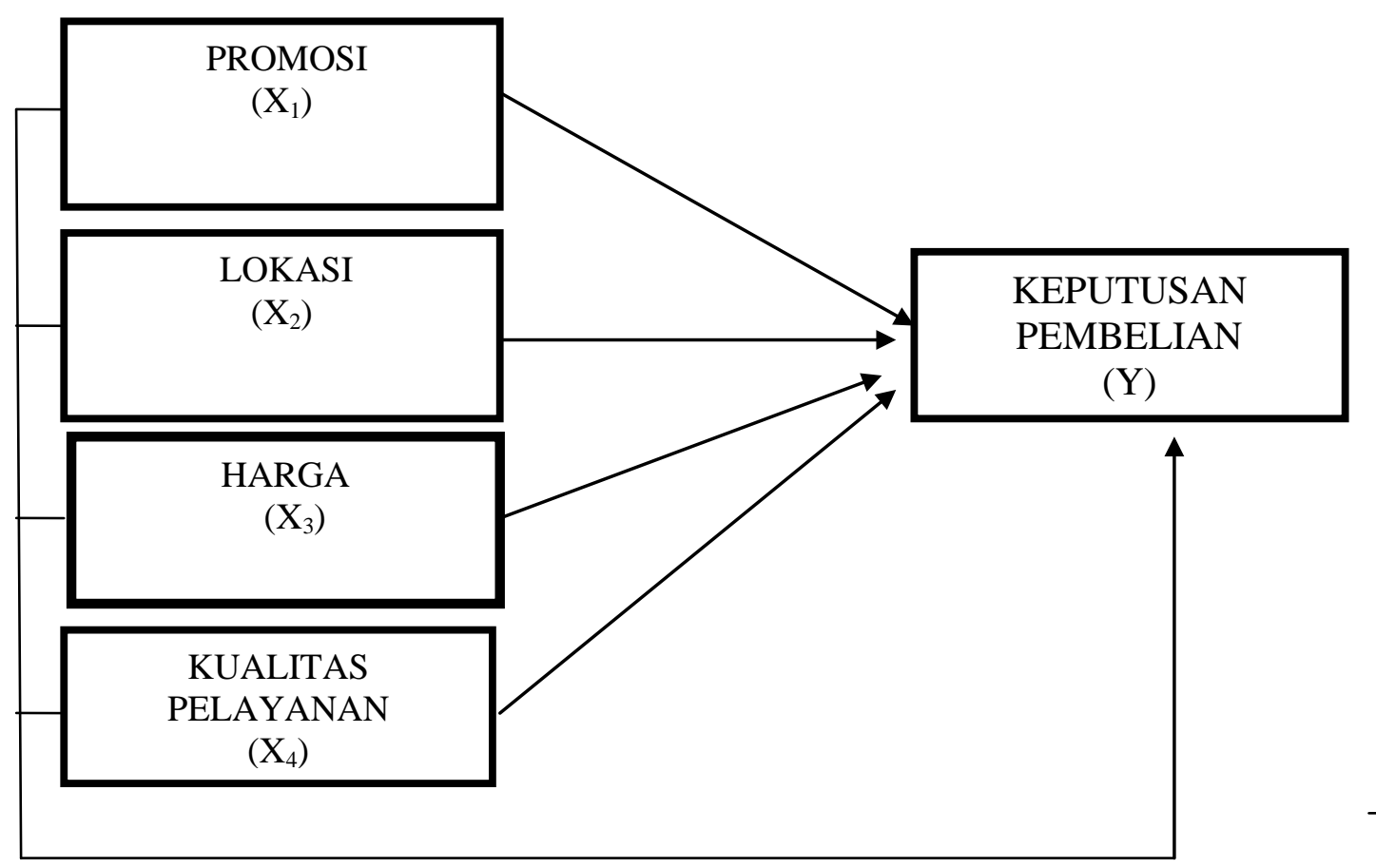

Sumber: Penulis (2017) 


\section{METODOLOGI PENELITIAN}

\subsection{Metode Penelitian}

Dalam penelitian ini metode penelitian yang digunakan adalah metode penelitian survei dengan pendekatan kuantitatif. Menurut (Sugiyono 2016), "Metode penelitian kuantitatif yaitu metode penelitian yang berlandaskan pada filsafat positivisme, digunakan untuk meneliti pada populasi atau sampel tertentu, pengumpulan data menggunakan instrumen penelitian, analisis data bersifat kuantitatif/statistik, dengan tujuan untuk menguji hipotesis yang telah ditetapkan”. Penelitian ini dilakukan dengan mengambil beberapa sampel dari suatu populasi dan menggunakan kuesioner sebagai alat pengumpul data.

\subsection{Tempat dan Waktu Penelitian}

Penelitian ini dilaksanakan di Roti Bakar 88, Jl. Kisamaun No.118, Pasar Lama Tangerang. Penelitian ini dilakukan selama 1 bulan di mulai dari tanggal 1 Maret 2017 sampai dengan 31 Maret 2017.

\subsection{Populasi dan Sampel}

1. Populasi

Populasi dalam penelitian ini yaitu seluruh konsumen yang datang untuk membeli di Roti Bakar 88 Tangerang dari tanggal 1 Maret 2017 sampai dengan 31 Maret 2017 sejumlah 2.500 orang.

\section{Sampel}

Dalam menentukan jumlah sampel menggunakan metode Slovin (Sugiyono, 2016:87):

$$
n=\frac{N}{1+N e^{2}}
$$

Dimana :

N= Jumlah Populasi (2500)

$\mathrm{n}=$ Ukuran sampel

e $=$ Kesalahan dalam pengambilan sampel, yaitu 10\%, maka:

$$
\mathrm{n}=\frac{2500}{1+2500(0,1)^{2}}
$$

$\mathrm{n}=96,15$

Dalam hasil perhitungan menggunakan metode Slovin, terhitung jumlah responden sebanyak 96,15 dimana dari hasil tersebut dibulatkan menjadi 100 respoden. Oleh karena itu penulis memilih sampel sebanyak 100 responden. 


\subsection{Teknik Pengambilan Sampel}

Dalam penelitian ini teknik sampling yang akan digunakan adalah dengan menggunakan metode Non Probability Sampling. Menurut Sugiyono (2016:84) "Non Probability Sampling adalah teknik pengambilan sampel yang tidak memberi peluang/kesempatan sama bagi setiap unsur atau anggota populasi untuk dipilih menjadi sampel”. Jenis teknik sampling yang digunakan pada penelitian ini yaitu accidental sampling yang merupakan teknik penentuan sampel berdasarkan kebetulan, yaitu siapa saja yang secara kebetulan/incidental bertemu dengan peneliti dapat digunakan sebagai sampel, bila dipandang orang yang kebetulan ditemui itu cocok sebagai sumber data (Sugiyono, 2016:85). Jenis pengambilan data yang dilakukan oleh penulis adalah kuesioner. Kuesioner adalah pernyataan tertulis yang digunakan untuk memperoleh informasi dari responden dalam arti laporan tentang pribadi atau hal-hal yang ia ketahui (Arikunto, 2013).

Bentuk pertanyaan dalam kuesioner mengenai promosi, lokasi, harga dan kualitas pelayanan yang menggunakan rating scale yang menyatakan sikap responden dalam kaitannya dengan promosi, lokasi, harga dan kualitas pelayanan dalam suatu tingkatan skala 1-5. Sampel yang digunakan dalam penelitian adalah sebanyak 100 orang.

\subsection{Teknik Analisis Data}

\subsubsection{Analisis Validitas dan Reliabilitas}

Validitas menurut Arikunto dalam Priyatno (2013:19) adalah "suatu ukuran yang menunjukkan tingkat kesahihan suatu instrument penelitian". Suatu instrument penelitian yang valid mempunyai validitas yang tinggi, sebaliknya instrument yang kurang valid berarti memiliki validitas yang rendah. Uji validitas yang akan dibahas dalam penelitian ini adalah validitas item kuesioner. Uji reliabilitas menurut Priyatno (2013:30) adalah "suatu alat pengukur dikatakan reliabel bila alat itu dalam mengukur suatu gejala pada waktu yang berlainan senantiasa menunjukkan hasil yang sama”. Jadi alat yang reliabel secara konsisten memberi hasil ukuran yang sama. Metode uji reliabilitas yang sering digunakan adalah Cronbach's Alpha.

Tabel 3.1

\section{Tingkat Hubungan Reliabilitas}

\begin{tabular}{|c|c|}
\hline Alpha & Tingkat Reliabilitas \\
\hline $0,00 \mathrm{~s} / \mathrm{d} 0,20$ & Kurang Reliabel \\
\hline $0,20 \mathrm{~s} / \mathrm{d} 0,40$ & Agak Reliabel \\
\hline $0,40 \mathrm{~s} / \mathrm{d} 0,60$ & Cukup Reliabel \\
\hline $0,60 \mathrm{~s} / \mathrm{d} 0,80$ & Reliabel \\
\hline $0,80 \mathrm{~s} / \mathrm{d} 1,00$ & Sangat Reliabel \\
\hline
\end{tabular}

Sumber: Priyatno (2013:30)

Menurut Ghozali dalam Priyatno (2013:30) "alat ukur dapat dikatakan reliabel jika nilai reliabilitas > 0,60 di mana 0,60 adalah standarisasi nilai reliabilitas”.

\subsubsection{Uji Normalitas}

Menurut (Ghozali, 2013:110) “Tujuan dari uji normalitas adalah untuk mengetahui apakah masing-masing variabel berdistribusi normal atau tidak. Uji normalitas diperlukan karena untuk 
melakukan pengujian-pengujian variabel lainnya dengan mengasumsikan bahwa nilai residual mengikuti distribusi normal”. Uji asumsi klasik pada penelitian ini menggunakan uji P-Plot.

\subsubsection{Uji Multikolinearitas}

Multikolinearitas adalah keadaan di mana terjadi hubungan linear yang sempurna atau mendekati sempurna antar variabel terikat dalam model regresi. Suatu model regresi dikatakan mengalami multikolinearitas jika ada fungsi linear yang sempurna pada beberapa atau semua variabel dalam fungsi linear, Priyatno (2013:56). Dan hasilnya sulit didapatkan pengaruh antara variabel bebas dan variabel terikat. Model regresi yang baik seharusnya tidak terjadi korelasi di antara variabel bebas. Cara untuk mengetahui ada atau tidaknya gejala multikolinearitas antara lain dengan melihat Variance Inflation Factor (VIF) dan Tolerance, apabila VIF kurang dari 10 dan Tolerance lebih dari 0,1 maka dinyatakan tidak terjadi multikolinearitas.

\subsubsection{Uji Heteroskedastisitas}

Heteroskedastisitas menurut Priyatno (2013:62) adalah "keadaan dimana terjadi ketidaksamaan varian dari residual untuk semua pengamatan pada model regresi”. Model regresi yang baik adalah tidak terjadi masalah heteroskedastisitas. Ada beberapa metode yang bisa digunakan untuk uji heteroskedastisitas yaitu Spearman's Rho testing, glejser testing, dan grafik regresi. Dalam penelitian ini penulis menggunakan metode grafik, yaitu dengan melihat pola titik-titik pada scatterplot regresi.

\subsubsection{Analisis Regresi Berganda}

Dalam penelitian ini, melalui analisis regresi linier berganda akan diketahui juga variabel manakah diantara variabel promosi $\left(\mathrm{X}_{1}\right)$, lokasi $\left(\mathrm{X}_{2}\right)$, harga $\left(\mathrm{X}_{3}\right)$, dan kualitas pelayanan $\left(\mathrm{X}_{4}\right)$ dimaksud yang paling berpengaruh terhadap keputusan pembelian (Y). Persamaan regresi linier berganda adalah:

Keterangan:

$$
\mathbf{Y}=\mathbf{a}+\boldsymbol{\beta}_{1} \mathrm{X}_{1}+\boldsymbol{\beta}_{2} \mathrm{X}_{2}+\boldsymbol{\beta}_{3} \mathrm{X}_{3}+\boldsymbol{\beta}_{4} \mathrm{X}_{4}+\mathbf{e}
$$

\begin{tabular}{|c|c|}
\hline $\mathrm{Y}$ & = Variabel terikat yang diprediksikan (Keputusan Pembelian) \\
\hline $\mathrm{X}_{1}$ & $=$ Variabel bebas $($ Promosi) \\
\hline $\mathrm{X}_{2}$ & $=$ Variabel bebas (Lokasi) \\
\hline $\mathrm{X}_{3}$ & = Variabel bebas (Harga) \\
\hline $\mathrm{X}_{4}$ & = Variabel bebas (Kualitas Pelayanan) \\
\hline 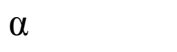 & $=$ Nilai konstanta \\
\hline$\beta_{1}, \beta_{2,} \beta_{3,} \beta_{4}$ & = Koefisien regresi \\
\hline & $=$ Error \\
\hline
\end{tabular}

\subsubsection{Uji Koefisien Korelasi (r)}

Analisis Koefisien Korelasi digunakan untuk mengetahui seberapa besar tingkat keeratan atau kekuatan hubungan antara variabel bebas dan variabel terikat dengan menggunakan korelasi Product Moment. Dalam memberikan penafsiran terhadap koefisien korelasi yang ditemukan tersebut besar atau kecil, maka dapat berpedoman pada interpretasi koefisien korelasi adalah sebagai berikut: 
Tabel 3.2

Tabel Koefisien Korelasi

\begin{tabular}{|l|c|}
\hline Interval Koefisien & Tingkat Hubungan \\
\hline $0,00-0,199$ & Sangat Rendah \\
\hline $0,20-0,399$ & Rendah \\
\hline $0,40-0,599$ & Sedang \\
\hline $0,60-0,799$ & Kuat \\
\hline $0,80-1,000$ & Sangat Kuat \\
\hline
\end{tabular}

Sumber: Sugiyono (2016:184)

\subsubsection{Analisis Koefisien Determinasi $\left(\mathbf{R}^{2}\right)$}

Koefisien determinasi $\left(\mathrm{R}^{2}\right)$ pada intinya mengukur seberapa jauh kemampuan model dalam menerangkan variasi variabel terikat (Ghozali, 2009). Nilai Koefisien determinasi adalah antara 0 (nol) dan 1 (satu). Nilai $\mathrm{R}^{2}$ yang kecil berarti kemampuan variabel-variabel bebas (promosi, lokasi, harga, dan kualitas pelayanan) dalam menjelaskan variasi variabel terikat (keputusan pembelian) amat terbatas. Begitu pula sebaliknya, nilai yang mendekati 1 (satu) berarti variabelvariabel bebas memberikan hampir semua informasi yang dibutuhkan untuk memprediksi variasi variabel terikat. Kelemahan mendasar penggunaan koefisien determinasi adalah bias terhadap jumlah variabel bebas yang dimasukkan kedalam model. Setiap tambahan satu variabel bebas, maka $\mathrm{R}^{2}$ pasti meningkat tidak perduli apakah variabel tersebut berpengaruh secara signifikan terhadap variabel terikat. Oleh karena itu, banyak peneliti menganjurkan untuk menggunakan nilai Adjusted $\mathrm{R}^{2}$ pada saat mengevaluasi mana model regresi yang terbaik. Tidak seperti $\mathrm{R}^{2}$, nilai Adjusted $\mathrm{R}^{2}$ dapat naik atau turun apabila satu variabel independen ditambahkan kedalam model.

\subsubsection{Uji Hipotesis}

\subsubsection{Uji Signifikan Pengaruh Parsial (Uji t)}

Uji t digunakan untuk mengetahui ada atau tidaknya pengaruh masing-masing variabel independent secara individual terhadap variabel dependent yang diuji pada tingkat signifikansi 0,05 (Ghozali, 2013).

Dengan rumus sebagai berikut:

$t=\frac{r \sqrt{n}-2}{\sqrt{1}-r^{2}}$

Dimana :

$r=$ koefisien regresi

$\mathrm{n}=$ jumlah sampel

$\mathrm{t}=$ uji Hipotesis

Kesimpulan keputusan:

1. Apabila $\mathrm{t}$ hitung $<\mathrm{t}$ tabel, maka Ho diterima yang berarti tidak ada pengaruh signifikan masing-masing variabel promosi $\left(\mathrm{X}_{1}\right)$, lokasi $\left(\mathrm{X}_{2}\right)$ harga $\left(\mathrm{X}_{3}\right)$, dan kualitas pelayanan $\left(\mathrm{X}_{4}\right)$ terhadap keputusan pembelian (Y). 
2. Apabila t hitung $>\mathrm{t}$ tabel, maka Ho ditolak yang berarti ada pengaruh signifikan antara masing-masing variabel promosi $\left(\mathrm{X}_{1}\right)$, lokasi $\left(\mathrm{X}_{2}\right)$ harga $\left(\mathrm{X}_{3}\right)$, dan kualitas pelayanan $\left(\mathrm{X}_{4}\right)$ terhadap keputusan pembelian (Y).

\subsubsection{Uji Signifikan Pengaruh Simultan (Uji Statistik F)}

Uji F digunakan untuk mengetahui pengaruh semua variabel independent secara bersama-sama terhadap variabel dependent yang diuji pada tingkat signifikan 0,05 (Ghoazali, 2013).

Kesimpulan :

a. Apabila $\mathrm{F}_{\text {hitung }}<\mathrm{F}_{\text {tabel }}$ maka Ho diterima dan Ha ditolak berarti tidak terdapat pengaruh yang signifikan antara promosi, lokasi, harga, dan kualitas pelayanan secara bersama-sama terhadap keputusan pembelian.

b. Apabila $\mathrm{F}_{\text {hitung }}>\mathrm{F}_{\text {tabel }}$ maka Ho ditolak dan Ha diterima, berarti terdapat pengaruh yang signifikan antara promosi, lokasi, harga, dan kualitas pelayanan secara bersama-sama terhadap keputusan pembelian.

\section{ANALISIS DAN PEMBAHASAN}

\subsection{Uji Validitas Dan Reliabilitas}

Dari hasil olah data dapat dilihat bahwa seluruh pertanyaan yang ada di kuesioner mengenai Promosi, Lokasi, Harga, Kualitas Pelayanan dan Keputusan Pembelian adalah valid dan reliable karena nilai $r$ hitung dari seluruh pertanyaan lebih besar dari nilai $r$ tabel $(0,1966)$ dengan nilai sig (2-tailed) $<0,05$ sehingga dapat disimpulkan bahwa semua item pernyataan tersebut valid dan nilai Cronbach's Alpha antara 0,6 sampai dengan 0,80 dikatakan reliabel

\subsection{Uji Normalitas}

\section{Gambar 4.1}

\section{Hasil Uji Normalitas}

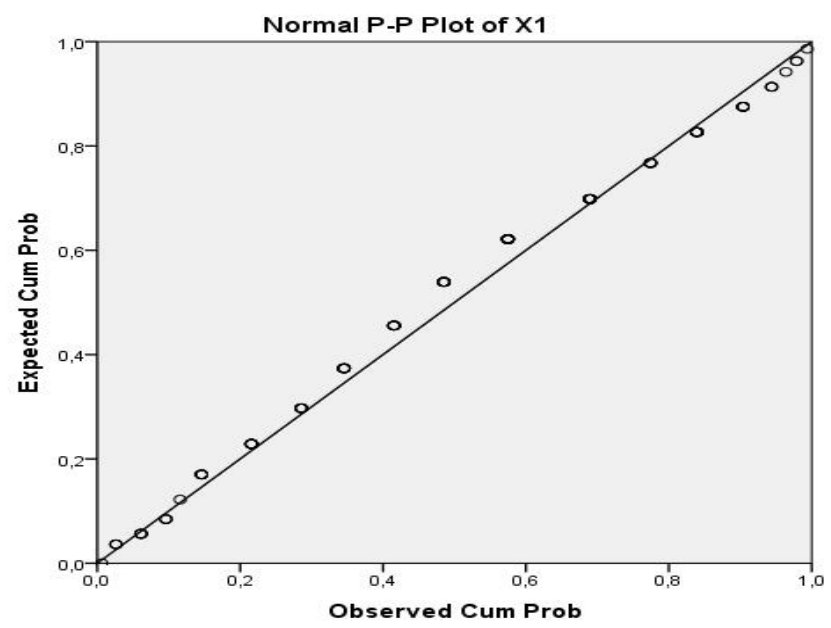

Pada gambar 4.1 di atas dapat diketahui bahwa titik-titik menyebar sekitar garis dan mengikuti garis diagonal, maka model regresi tersebut terdistribusi secara normal. 


\subsection{Uji Multikolinearitas}

Tabel 4.1

Hasil Uji Multikolinearitas

Coefficients $^{\mathrm{a}}$

\begin{tabular}{|c|c|c|}
\hline \multirow[b]{2}{*}{ Model } & \multicolumn{2}{|c|}{ Collinearity Statistics } \\
\hline & Tolerance & VIF \\
\hline \multicolumn{3}{|l|}{1 (Constant) } \\
\hline Promosi & ,861 & 1,161 \\
\hline Lokasi & ,736 & 1,359 \\
\hline Harga & ,374 & 2,671 \\
\hline Kualitas Pelayanan & 428 & 2,336 \\
\hline
\end{tabular}

a. Dependent Variabel: Keputusan Pembelian

Sumber: Data diolah SPSS 22.0 (2017)

Didapat hasil pada variabel Promosi, Lokasi, Harga, dan Kualitas Pelayanan nilai TOL $>0,1$ dan VIF $<10$, sehingga tidak ada masalah multikolinearitas.

\subsection{Uji Heteroskedastisitas}

Gambar 4.2

Hasil Uji Heteroskedastisitas

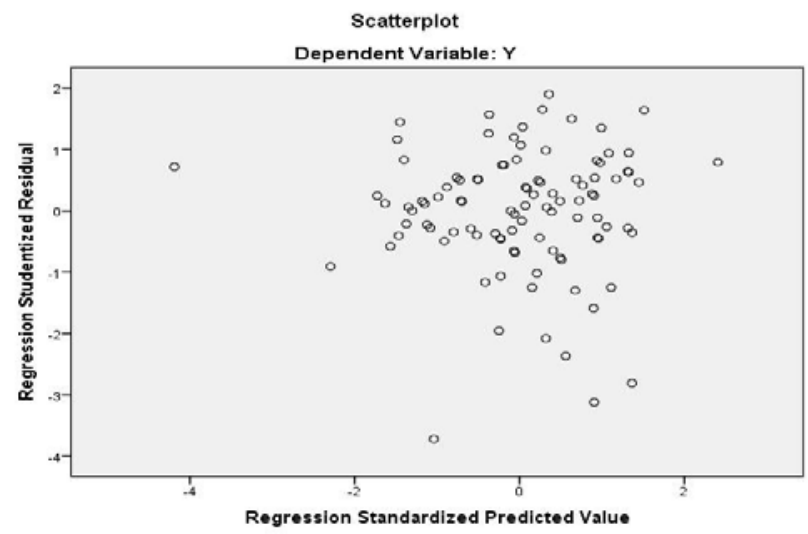

Sumber: Data diolah SPSS 22.0 (2017)

Berdasarkan hasil output uji heteroskedastisitas yang terlihat pada gambar 4.2 terlihat bahwa titiktitik menyebar secara acak serta tersebar baik diatas maupun dibawah angka 0 pada sumbu Y. Hal ini dapat disimpulkan bahwa tidak terjadi Heteroskedastisitas pada model regresi. 


\subsection{Analisis Regresi Berganda}

Hasil output tersebut dimasukkan dalam bentuk persamaan regresi berganda adalah sebagai berikut:

$$
\begin{gathered}
Y=\alpha+\beta_{1} X_{1}+\beta_{2} X_{2}+\beta_{3} X_{3}+\beta_{4} X_{4}+e \\
Y=6,796+0,117 X_{1}+0,184 X_{2}+0,196 X_{3}+0,420 X_{4}+e
\end{gathered}
$$

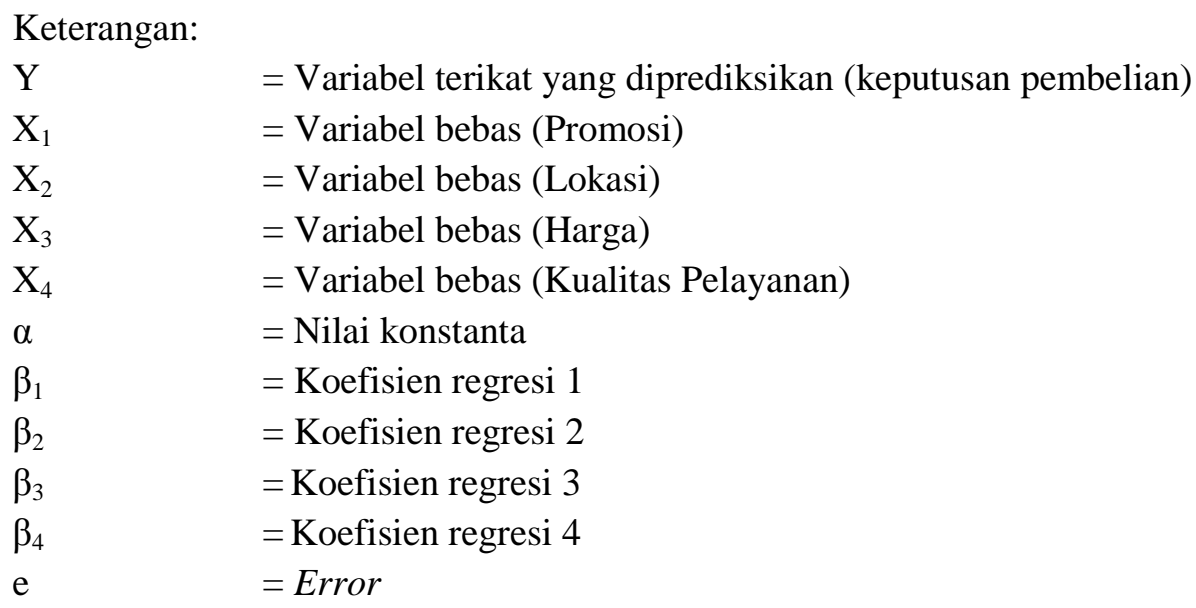

Dari uraian di atas maka:

1. Koefisien regresi variabel promosi $\left(\mathrm{X}_{1}\right)$ sebesar 0,117 artinya jika variabel promosi $\left(\mathrm{X}_{1}\right)$ mengalami kenaikan satu satuan, maka keputusan pembelian (Y) akan mengalami peningkatan sebesar 0,117 satuan dengan asumsi variabel bebas lainnya bernilai tetap.

2. Koefisien regresi variabel lokasi $\left(\mathrm{X}_{2}\right)$ sebesar 0,184 artinya jika variabel lokasi $\left(\mathrm{X}_{2}\right)$ mengalami kenaikan satu satuan, maka keputusan pembelian (Y) akan mengalami peningkatan sebesar 0,184 satuan dengan asumsi variabel bebas lainnya bernilai tetap.

3. Koefisien regresi variabel harga $\left(X_{3}\right)$ sebesar 0,196 artinya jika variabel mengalami kenaikan satu satuan, maka keputusan pembelian (Y) akan mengalami peningkatan sebesar 0,196 satuan dengan asumsi variabel bebas lainnya bernilai tetap.

4. Koefisien regresi variabel kualitas pelayanan $\left(\mathrm{X}_{4}\right)$ sebesar 0,420 artinya jika variabel mengalami kenaikan satu satuan, maka keputusan pembelian (Y) akan mengalami peningkatan sebesar 0,420 satuan dengan asumsi variabel bebas lainnya bernilai tetap.

\subsection{Koefisien Korelasi (R) Dan Koefisien Determinasi $\left(\mathbf{R}^{2}\right)$}

Berdasarkan output model summary diperoleh angka $\mathrm{R}$ sebesar 0,789. Hal ini menunjukkan bahwa terjadi hubungan yang kuat antara promosi, lokasi, harga, dan kualitas pelayanan terhadap keputusan pembelian. Sementara itu diketahui nilai Adjusted $R$ Square sebesar 0,606 atau 60,6\%. Hal ini menunjukkan bahwa variabel independent (promosi, lokasi, harga, dan kualitas pelayanan) memberikan kontribusi pengaruh 0,606 atau 60,6\% terhadap variabel dependent (keputusan pembelian). Sedangkan sisanya sebesar 0,394 atau 39,4\% dipengaruhi oleh faktor lain yang tidak dimasukkan dalam model penelitian ini. 


\subsection{Uji Hipotesis}

\subsubsection{Uji t (Parsial)}

Hasil uji t dapat dilihat dari hasil output:

\section{Variabel Promosi $\left(X_{1}\right)$}

Berdasarkan output pada diperoleh $\mathrm{t}_{\text {hitung }}$ untuk variabel Promosi $\left(\mathrm{X}_{1}\right)$ yaitu sebesar 2,222. Karena nilai $t_{\text {hitung }}>t_{\text {tabel }}(2,222>1,985)$ dengan nilai sig $(0,025<0,05)$ maka Ho ditolak, artinya bahwa Promosi $\left(\mathrm{X}_{1}\right)$ secara parsial berpengaruh signifikan terhadap Keputusan Pembelian (Y).

\section{Variabel Lokasi $\left(X_{2}\right)$}

Berdasarkan output pada diperoleh $\mathrm{t}_{\text {hitung }}$ untuk variabel Lokasi $\left(\mathrm{X}_{2}\right)$ yaitu sebesar 2,594. Karena nilai $t_{\text {hitung }}>t_{\text {tabel }}(2,954>1,985)$ dengan nilai sig $(0,011<0,05)$ maka Ho ditolak artinya, bahwa Lokasi $\left(\mathrm{X}_{2}\right)$ secara parsial berpengaruh signifikan terhadap Keputusan Pembelian (Y).

\section{Variabel Harga $\left(X_{3}\right)$}

Berdasarkan output pada di atas diperoleh $t_{\text {hitung }}$ untuk variabel Harga $\left(\mathrm{X}_{3}\right)$ yaitu sebesar 2,149. Karena nilai $t_{\text {hitung }}>t_{\text {tabel }}(2,149>1,985)$ dengan nilai sig $(0,034<0,05)$ maka Ho ditolak artinya, bahwa Harga $\left(\mathrm{X}_{3}\right)$ secara parsial berpengaruh signifikan terhadap Keputusan Pembelian (Y).

\section{Variabel Kualitas Pelayanan $\left(\mathrm{X}_{4}\right)$}

Berdasarkan output pada diperoleh $\mathrm{t}_{\text {hitung }}$ untuk variabel Kualitas Pelayanan $\left(\mathrm{X}_{4}\right)$ yaitu sebesar 5,103 . Karena nilai $t_{\text {hitung }}>t_{\text {tabel }}(5,103>1,985)$ dengan nilai sig $(0,000<0,05)$ maka Ho ditolak artinya, bahwa Kualitas Pelayanan $\left(\mathrm{X}_{4}\right)$ secara parsial berpengaruh signifikan terhadap Keputusan Pembelian (Y).

\subsubsection{Uji F (Simultan)}

Hasil output diketahui nilai F-Sig. adalah 0,000 artinya bahwa $p$-value $<\alpha$ atau $0,000<0,05$ sehingga keputusan yang diambil adalah Ho ditolak dan Ha diterima. Hal ini menunjukan bahwa secara bersama-sama (simultan) terdapat pengaruh yang signifikan antara promosi $\left(\mathrm{X}_{1}\right)$, lokasi $\left(\mathrm{X}_{2}\right)$, harga $\left(\mathrm{X}_{3}\right)$ dan kualitas pelayanan $\left(\mathrm{X}_{4}\right)$ terhadap keputusan pembelian (Y). Sedangkan jika penentuan keputusan dengan cara membandingkan $\mathrm{F}_{\text {hitung }}$ dengan $\mathrm{F}_{\text {tabel }}$. diperoleh $\mathrm{F}_{\text {hitung }}$ sebesar 39,063 sehingga $F_{\text {hitung }}>F_{\text {tabel }}(39,063>2,47)$ maka Ho ditolak dan Ha diterima yang artinya promosi $\left(\mathrm{X}_{1}\right)$, lokasi $\left(\mathrm{X}_{2}\right)$, harga $\left(\mathrm{X}_{3}\right)$ dan kualitas pelayanan $\left(\mathrm{X}_{4}\right)$ secara simultan (bersama-sama) berpengaruh signifikan terhadap keputusan pembelian (Y) pada Roti Bakar 88 Tangerang.

\section{SIMPULAN DAN SARAN}

\subsection{SIMPULAN}

Berdasarkan hasil penelitian, maka dapat ditarik simpulan sebagai berikut:

1. Berdasarkan hasil analisis uji t, diketahui nilai $t_{\text {hitung }}>t_{\text {tabel }}$ yaitu sebesar 2,222 $>1,985$ dan nilai signifikansi (Sig) 0,025 < 0,05 maka dapat disimpulkan bahwa Ho ditolak, artinya bahwa promosi secara parsial berpengaruh signifikan terhadap keputusan pembelian pada Roti Bakar 88 Tangerang.

2. Berdasarkan hasil analisis uji t, diketahui nilai $t_{\text {hitung }}>t_{\text {tabel }}$ sebesar 2,594 $>1,985$ dan nilai signifikansi (Sig) 0,011 < 0,05 maka dapat disimpulkan Ho ditolak, artinya bahwa lokasi secara parsial berpengaruh signifikan terhadap keputusan pembelian pada Roti Bakar 88 Tangerang. 
3. Berdasarkan hasil analisis uji t, diketahui nilai $t_{\text {hitung }}>t_{\text {tabel }}$ sebesar 2,149 $>1,985$ dan nilai signifikansi (Sig) 0,34< 0,05 maka dapat disimpulkan Ho ditolak, artinya bahwa harga secara parsial berpengaruh signifikan terhadap keputusan pembelian pada Roti Bakar 88 Tangerang.

4. Berdasarkan hasil analisis uji t, diketahui nilai $t_{\text {hitung }}>t_{\text {tabel }}$ sebesar 5,103 $>1,985$ dan nilai signifikansi (Sig) 0,000 < 0,05 maka dapat disimpulkan Ho ditolak, artinya bahwa kualitas pelayanan secara parsial berpengaruh signifikan terhadap keputusan pembelian pada Roti Bakar 88 Tangerang.

5. Berdasarkan hasil analisis uji F, diketahui untuk variabel promosi, lokasi, harga dan kualitas pelayanan dengan nilai $F_{\text {hitung }}$ sebesar 39,063 dengan $F_{\text {tabel }}$ sebesar 2,47 karena nilai $F_{\text {hitung }}$ sebesar 39,063 > nilai $\mathrm{F}_{\text {tabel }}$ sebesar 2,47 dan nilai signifikansinya sebesar 0,000 < 0,05 maka dapat disimpulkan Ho ditolak dan Ha diterima artinya promosi, lokasi, harga, dan kualitas pelayanan berpengaruh secara simultan atau bersama-sama terhadap keputusan pembelian pada Roti Bakar 88 Tangerang.

\subsection{SARAN}

Berdasarkan simpulan yang diperoleh dalam penelitian ini, maka diajukan sara-saran sebagai pelengkap terhadap hasil penelitian sebagai berikut:

1. Promosi memberikan pengaruh terhadap keputusan pembelian. Hal ini berarti Roti Bakar 88 Tangerang perlu meningkatkan promosi kepada masyarakat. Karena promosi yang baik dapat mengingatkan dan mempengaruhi keputusan pembelian dan juga dapat menciptakan konsumen baru yang potensial apabila promosi dilakukan di tempat-tempat yang belum tersentuh Roti Bakar 88 Tangerang.

2. Lokasi memberikan pengaruh terhadap keputusan pembelian. Hal ini berarti Roti Bakar 88 Tangerang sebagai penyedia jasa kuliner perlu memperhatikan lokasi yang menjadi salah satu faktor penting yang berpengaruh secara langsung terhadap keputusan pembelian. Oleh Karena itu, lokasi bisa dijadikan prioritas untuk merangsang minat beli. Usaha yang dapat dilakukan oleh Roti Bakar 88 misalnya dengan cara menyediakan lahan parkir untuk kendaraan roda empat.

3. Harga berpengaruh signifikan terhadap keputusan pembelian. Hal ini berarti Roti Bakar 88 Tangerang perlu memperhatikan beberapa faktor dalam penetapan harga, selain memperhatikan unsur biaya, juga memperhatikan harga yang ditetapkan pesaing. Berdasarkan hal tersebut sebaiknya Roti Bakar 88 mengeluarkan kebijakan-kebijakan mengenai harga yang sesuai dengan keinginan/kebutuhan para pelangganya untuk dapat terus mempertahankan dan meningkatkan penjualan.

4. Kualitas pelayanan memberikan pengaruh dominan terhadap keputusan pembelian. Dalam hal ini Roti Bakar 88 Tangerang secara keseluruhan dinilai responden sudah baik, akan tetapi manajemen dirasa perlu lebih memberikan pengarahan khususnya kepada para pelayan agar selalu bersikap ramah serta lebih cepat dan tanggap terhadap keinginan dan permintaan pelanggan, dimana pelayan merupakan pihak yang secara langsung berinteraksi dan melayani para pelanggan. Dengan begitu Roti Bakar 88 Tangerang akan mampu memenangkan persaingan serta dapat memberikan kenyamanan dan kepuasan yang maksimal kepada semua konsumen. Sehingga mampu menumbuhkan kepercayaan dan loyalitas yang tinggi agar selalu menempatkan Roti Bakar 88 Tangerang sebagai pilihan utama. 


\section{DAFTAR PUSTAKA}

Abdullah, Thamrin dan Francisca, Tantri. 2016. Manajemen Pemasaran. Edisi 1 Cetakan 5. PT Rajagrafindo Persada. Jakarta.

Alma, Buchori. 2013. Manajemen Pemasaran dan Manajemen Jasa. CV Alfabeta. Bandung.

Anwar, Sanusi. 2010. Metode Penelitian Bisnis. Salemba Empat. Jakarta.

Dharmmesta, Basu Swastha. 2008. Manajemen Pemasaran Modern. Liberty. Yogyakarta.

Dharmmesta, Basu Swastha dan Irawan. 2011. Manajemen Pemasaran Modern. Edisi Kedua, Cetakan Ke-tigabelas. Liberty Offset. Yogyakarta.

Christina Widya Utami. 2008. Manajemen Barang Dagangan dalam Bisnis Riteil. Publishing Bayumedia. Malang.

Danang, Sunyoto. 2014. Konsep Dasar Riset Pemasaran \& Perilaku Konsumen. CAPS. Yogyakarta.

Ghozali, Imam. 2013. Aplikasi Analisis Multivariate Dengan Program SPSS. Cetakan Keempat. Badan Penerbit Universitas Diponegoro. Semarang.

Goenadhi, Lydia. 2011. Faktor-Faktor yang Mempengaruhi Perilaku Konsumen Dalam Keputusan Pembelian Mobil Toyota Avanza di Kota Banjarmasin. Jurnal Manajemen dan Akuntansi. Vol.12, No.2.

Hasibuan, Malayu. 2013. Manajemen: Dasar, Pengertian dan Masalah. Bumi Aksara Jakarta.

Hurriyati, Ratih. 2010. Bauran Pemasaran dan Loyalitas Konsumen. Alfabeta. Jakarta.

Lupiyoadi, Rambat. 2009. Manajemen Pemasaran Jasa. Edisi kedua. Penerbit Salemba Empat. Jakarta.

2014. Manajemen Pemasaran Jasa Berbasis Kompetensi. Edisi ketiga. Penerbit Salemba Empat. Jakarta.

Machfoedz, Mahmud. 2010. Komunikasi Pemasaran. Edisi Pertama. Cetakan Pertama. Cakra Ilmu. Yogyakarta.

Priyatno, Duwi. 2013. Analisis Korelasi, Regersi, dan Multivariate dengan SPSS. Gava Media. Yogyakarta.

Poter, PJ dan Olson, JC. 2010. Consumer Behavior and Marketing Strategi. The Mc Graw Hill. New York.

Saladin, Djaslim. 2010. Manajemen Pemasaran. Edisi Pertama. CV Linda Karya. Bandung. 